УДК 624.016

\title{
ОПТИМІЗАЦІЯ РОЗМІРІВ СТАЛЕЗАЛІЗОБЕТОННИХ БАЛОК ПРИ ЇХ РОЗРАХУНКУ ЗГІДНО 3 ВИМОГАМИ ДСТУ-Н Б ЕN 1994-1-1:2010
}

\author{
Кандидати техн. наук А.В. Гасенко, С.А. Гудзь, В.В. Дарієнко \\ ОПТИМИЗАЦИЯ РАЗМЕРОВ СТАЛЕЖЕЛЕЗОБЕТОННЫХ БАЛОК ПРИ ИХ РАСЧЕТЕ \\ СОГЛАСНО ТРЕБОВАНИЯМ ДСТУ-Н Б ЕN 1994-1-1:2010
}

\author{
Кандидаты техн. наук А.В. Гасенко, С.А. Гудзь, В.В. Дариенко \\ OPTIMIZATION OF DIMENSIONS OF THE COMPOSITE STEEL CONCRETE BEAMS IN
CALCULATING ACCORDING TO THE REQUIREMENTS OF DSTU-N B EN 1994-1-4:2010
}

Cand. of techn. sciences A. Gasenko, S. Gudz, V. Darienko

У статті описано варіант виявлення запасу несучої здатності сталезалізобетонного перекриття при проведенні розрахунку згідно з вимогами ДСТУ-Н Б ЕN 1994-1-1:2010 за рахунок урахуванням сумісної роботи монолітної залізобетонної плити перекриття, що влаштована по незнімному сталевому профільованому настилу, та сталевої балки, які з’єднані за допомогою приварювання шпильок за технологією «Нельсон».

Ключові слова: сталеві балки, анкерні шпильки, бетон, арматура, плити перекриття.

В статье описан вариант определения запаса несущей способности сталежелезобетонного перекрытия при проведении его расчета согласно требованиям ДСТУ-Н Б ЕN 1994-1-1:2010 при учете совместной работы монолитной железобетонной плиты перекрытия, которая устраивается по неизвлекаемому стальному профнастилу, и стальной балки, которые соединены с помощью приваривания шпилек по технологии «Нельсон».

Ключевые слова: стальные балки, анкерные шпильки, бетон, арматура, плиты перекрытия.

The article is described of the national annex for DSTU-N B EN 1994-1-1:2010 four classes crosssections of composite steel concrete slab, depending on the aspect ratio of the compression flange or steel beam, the provisions of the zero line, the degree of reinforcement. The main stages of the simplified calculation of the bearing capacity of such beams. Is described the variant of definition the bearing capacity of the composite steel concrete slab reserve as an example of replacing the secondary beams of the main project, made in the form of a welded I-beam $398 \times 6 \times 200 \times 12 \mathrm{~mm}$ on the I-beam №36 of hot-rolled profile with the collaboration of monolithic reinforced concrete slabs with a thickness of $150 \mathrm{~mm}$, arranged by an nonremovable steel professional flooring №57-0,7 which is connected to the steel beam by welding the studs type KB 16×125, welded by the technology «Nelson».

Keywords: steel beams, anchors studs, concrete, armature, slabs.

Вступ. Під час нового будівництва, а також капітального ремонту будівель громадського чи промислового призначення, що мають значні прольоти перекриття, розрахованого на великі навантаження, все частіше застосовуються сталезалізобетонні статично невизначні (нерозрізні) балки $[6,7$, 11]. Зусилля розтягу в таких балках сприймає сталева частина, i виключається можливість місцевої втрати іï стійкості [2]. Зусилля стиску сприймає бетонна частина. Зменшити витрати на спорудження такого типу конструкцій можна шляхом урахування перерозподілів зусиль між матеріалами комбінованих елементів (між сталлю та бетоном), таким чином зменшуючи загальні поперечні перерізи елементів $[4,10]$.

Постановка проблеми у загальному вигляді та ії зв'язок із важливими науковими та практичними завданнями. Оскільки до складу стиснутого пояса сталезалізобетонної балки входить потужна залізобетонна плита, момент інерції об'єднаного перерізу різко збільшується (а 
отже, збільшується жорсткість балки і зменшуються прогини балки) [7]. Тому сталезалізобетонні балки можуть влаштовуватися значно нижчими від сталевих, при одночасній економії сталі. Сталезалізобетонні балки досить економічні у випадках, коли залізобетонна плита $\epsilon$ обов'язковим елементом конструкції. Об'єднання плити і балок дає істотну економію в балкових клітках робочих площадок [10]. Актуальність роботи обгрунтована всезростаючим впровадженням сталезалізобетонних конструкцій у практику будівництва в Україні при відсутності відповідних державних будівельних норм.

Аналіз останніх досліджень і публікацій $[5,8]$ показав, що важливим залишається питання вибору оптимальних розмірів та конструкції елементів поєднання двох матеріалів для сумісної роботи. Застосування 3'єднувальних анкерів недостатньої міцності чи малої жорсткості зумовлюе взаємне проковзування сталевої та залізобетонної частин перерізу, зменшує несучу здатність i збільшує прогини конструкції [9]. На загальну несучу здатність і деформативність сталезалізобетонної балки також впливають схильність до втрати місцевої та загальної стійкості сталевої балки, історія навантаження [7].

Виділення не розв'язаних раніше частин загальної проблеми. Не повністю розкритим залишилося питання роботи конструкції анкерів для забезпечення сумісної роботи бетону та сталі, особливо у місцях дії позитивного згинального моменту в бетоні, де останній працює на розтяг.

Метою роботи $\epsilon$ опис можливості зменшення поперечних перерізів складових композитного сталезалізобетонного перекриття за рахунок врахування сумісної їх роботи згідно з вимогами ДСТУ-Н Б ЕN 1994-1-1:2010.

Основний матеріал і результати. В європейських нормах EN 1994-1-1 Eurocode 4 [10] та адаптованих згідно 3 [1] для України національних додатків ДСТУ-Н Б ЕN 1994-11:2010 (Сврокод 4) [4] розрізняють 4 класи поперечних перерізів залежно від співвідношення розмірів стиснутої полички або стінки сталевої балки, положення нульової лінії, ступеня армування. Клас поперечного перерізу зумовлює метод визначення внутрішніх зусиль і несучої здатності поперечного перерізу. Граничні значення для класифікації поперечних перерізів сталезалізобетонних балок наведені на рис. 1 [3].

Для поперечних перерізів класу 1 (пластичних перерізів) можливий повний перерозподіл внутрішніх зусиль системи 3 утворенням пластичного шарніру. Балки 3 компактними (щільними) поперечними перерізами класу 2 також можуть розвивати повну пластичну несучу здатність. Але обертання пластичного шарніру обмежується місцевим випучуванням i/aбо руйнуванням бетону. При визначенні внутрішніх зусиль потрібно враховувати перерозподіл згинального моменту внаслідок утворення тріщин і часткової пластифікації перед появою першого пластичного шарніру. При поперечних перерізах класу 3 (напівкомпактних перерізах) в стиснутій поличці сталевої балки можливе тільки пружне використання перерізу аж до межі плинності сталі. Перерозподіл моменту можливий лише через утворення тріщин в бетоні та через текучість розтягнутої сталевої частини. Гнучкі поперечні перерізи класу 4 не використовуються до межі плинності сталі через локальні випинання стиснутої сталевої частини. Перерозподіл моменту викликається лише утворенням тріщин в бетоні.

Розглянемо основні етапи спрощеного розрахунку несучої здатності сталезалізобетонних балок i виділимо ті моменти, на які потрібно звертати особливу увагу. Обмежимось найпоширенішими класами поперечних перерізів, для котрих можливе визначення несучої здатності як пластичного згинального моменту за методом граничної рівноваги (класи 1 і 2).

Розрахунок на обмеження деформацій потребує значних затрат часу, оскільки визначальний деформований стан повинен розраховуватись багатократно (ітераційно). Тому для практичного розрахунку роблять деякі спрощення. Для пластичних і компактних поперечних перерізів визначається пластичний момент за методом граничної рівноваги, для напівкомпактних і гнучких - пружний, до того ж для гнучких поперечних перерізів слід враховувати втрату місцевої стійкості внаслідок дії нормальних напружень. Якщо переріз сприймає одночасно згинальний момент і поперечну силу, то при їх взаємодії слід додатково звертати увагу на вплив втрати місцевої стійкості від зсуву. При розрахунку пластичного моменту опору приймаються такі 
допущення i передумови: в поперечному перерізі сталевої балки діють напруження розтягу i/або стиску 3 розрахунковим значенням межі плинності конструкційної сталі; в арматурі в області робочої ширини плити діють напруження розтягу i/або стиску 3 розрахунковим значенням межі плинності; в стиснутій зоні бетонного поперечного перерізу між пластичною нульовою лінією і крайнім волокном бетонного перерізу приймається розрахункове значення міцності бетону на стиск. Формула для визначення (повно) пластичного моменту вибирається залежно від положення пластичної нульової лінії, котра може розташовуватися в залізобетонній плиті вище або нижче другого ряду арматурних стрижнів, який потрібен для сприйняття зусиль розтягу при роботі залізобетонної плити на згин; в поличці сталевої балки; в стінці сталевої балки (табл. 1).
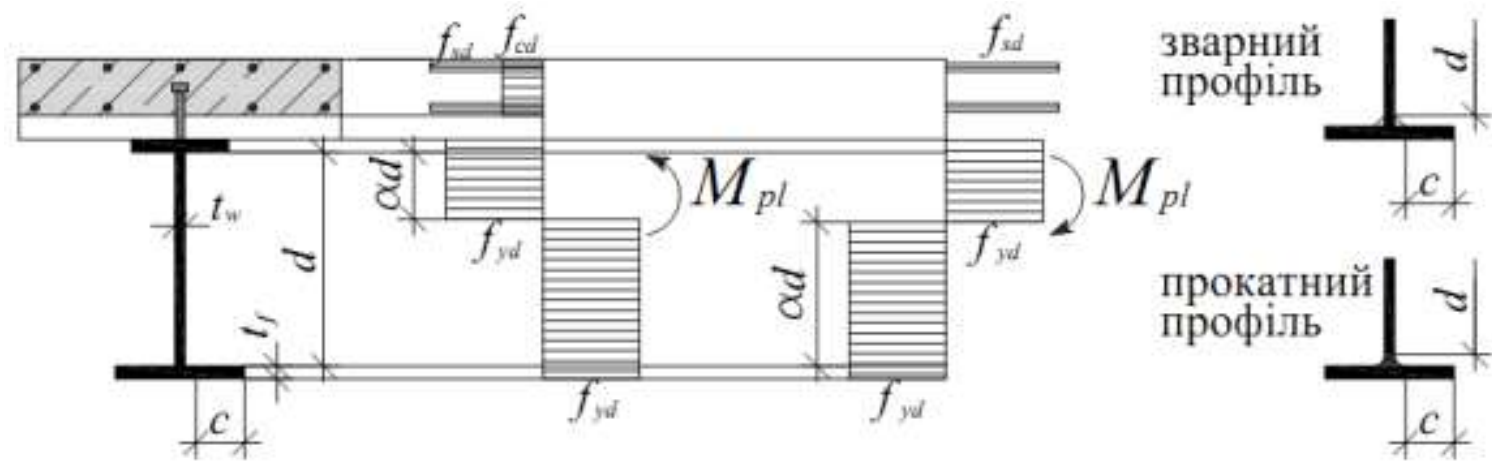

\begin{tabular}{|c|c|}
\hline Клас 1 & Клас 2 \\
\hline 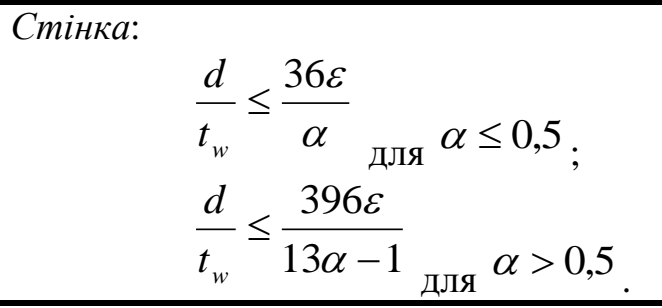 & 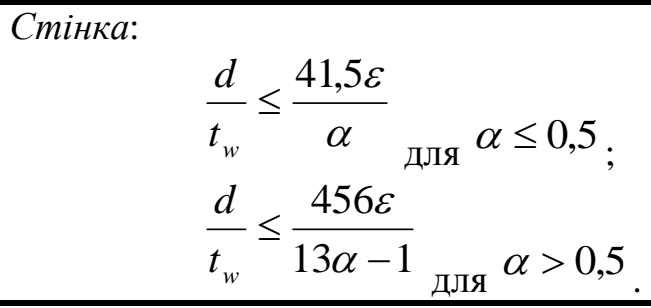 \\
\hline $\begin{array}{l}\text { Поличка: } \\
\qquad \begin{array}{l}c / t_{f} \leq 9 \varepsilon \\
c / t_{f} \leq 10 \varepsilon\end{array} \text { для зварного профілю; } \\
\text { для прокатного профілю. }\end{array}$ & $\begin{array}{l}\text { Поличка: } \\
\qquad / t_{f} \leq 10 \varepsilon \\
c / t_{f} \leq 11 \varepsilon \quad \text { для зварного профілю; }\end{array}$ \\
\hline$\varepsilon=\sqrt{\frac{235}{f_{y k}[M \Pi a]}}$ & $\varepsilon=\sqrt{\frac{235}{f_{y k}[M \Pi a]}}$ \\
\hline
\end{tabular}

Рис. 1. Класифікація поперечних перерізів сталезалізобетонних балок для поперечних перерізів класів 1 і 2 за EN 1994-1-1 [4, 10]

Позначення в табл. 1:

$$
\begin{aligned}
& N_{p l, a, R d}=f_{y d} A_{a} ; \\
& N_{f 1}=2 f_{y d} b_{f}\left(z_{p l}-h_{c}\right) ; \\
& N_{w}=2 f_{y d} t_{w}\left(z_{p l}-h_{c}-t_{f}\right) ; \\
& N_{c d}=0,85 f_{c d} b_{e f f}\left(h_{c}-h_{p}\right) ;
\end{aligned}
$$

$$
\begin{aligned}
& N_{f}=2 f_{y d} b_{f} t_{f} ; \\
& N_{s, i}=f_{s d} A_{s, i} .
\end{aligned}
$$

Одним із проектів, у якому отримано дійсне зниження вартості будівництва за рахунок зменшення поперечного перерізу конструктивних елементів, $є$ будівництво 
торгово-офісного комплексу 3 паркінгами у м. Київ. За результатами розрахунку перевірена можливість заміни другорядної балки основного проекту із врахуванням сумісної роботи монолітної залізобетонної плити перекриття, що влаштована по незнімному сталевому профільованому настилу Н57-0,7, 3'єднаному зі сталевою балкою за допомогою приварювання шпильок типу КВ $16 \times 125$ за технологією «Нельсон» (Nelson $®)$.

Таблиця 1

Визначення розрахункового значення несучої здатності сталезалізобетонної балки за згинальним моментом у пластичній стадії

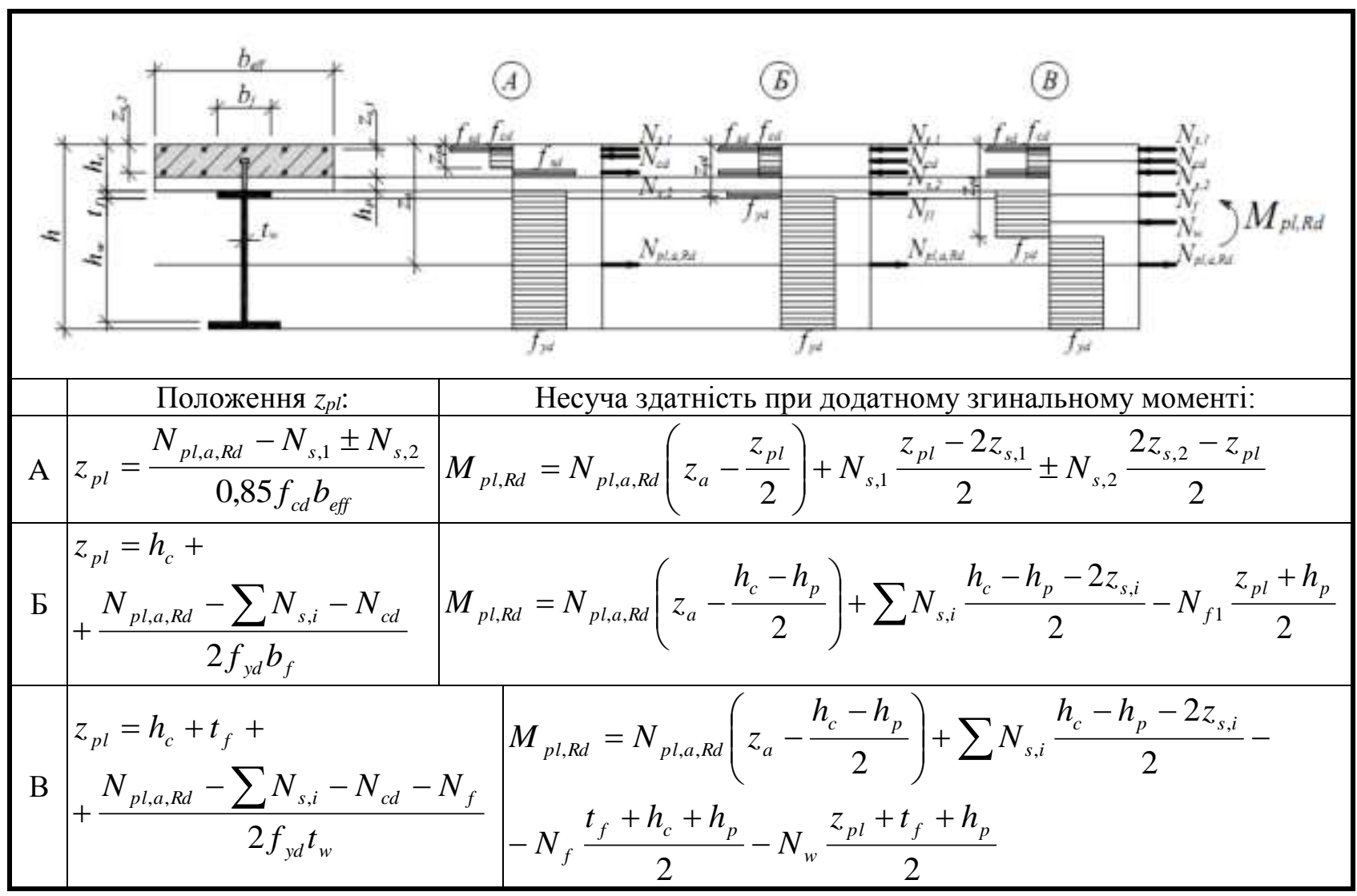

Компанія Nelson ${ }^{\circledR} \quad$ Bolzenschweiss Technik Gmbh \& Co.KG (Німеччина), заснована ще в 1936 році, є визнаним лідером світового ринку в технологіях виготовлення i приварювання елементів кріплення. На сьогодні вона включає завод 3 виробництва елементів кріплення і керамічних кілець більше ніж 400 типорозмірів, у тому числі деталей із зовнішнім різьбленням, анкерів, що працюють на зріз, підвісок для труб і кабелів, зварних шпильок і бобишок, а також устаткування для їх приварювання.

Процес приварювання анкера складається 3 декількох етапів i здійснюється в автоматичному режимі, що унеможливлює вплив людського чинника на якість приварювання. Електрична дуга - дуговий розряд між шпилькою й основною заготовки створює з'єднання розплавленого металу, обмеженого керамічним запобіжним кільцем, яке виконує роль флюсу та дозволяє шпильці автоматично занурюватися в лунку. Технологія «Нельсон» дозволяє об'єднати сталеві та залізобетонні конструкції в єдину сталезалізобетонну, забезпечивши їх спільну роботу, i тим самим знизити витрату матеріалів до $20 \%$ [5].

У початковому варіанті основного проекту торгово-офісного комплексу другорядною балкою перекриття $\epsilon$ зварний двотавр розміром $398 \times 6 \times 200 \times 12$ мм, показаний на рис. 2. 
a)

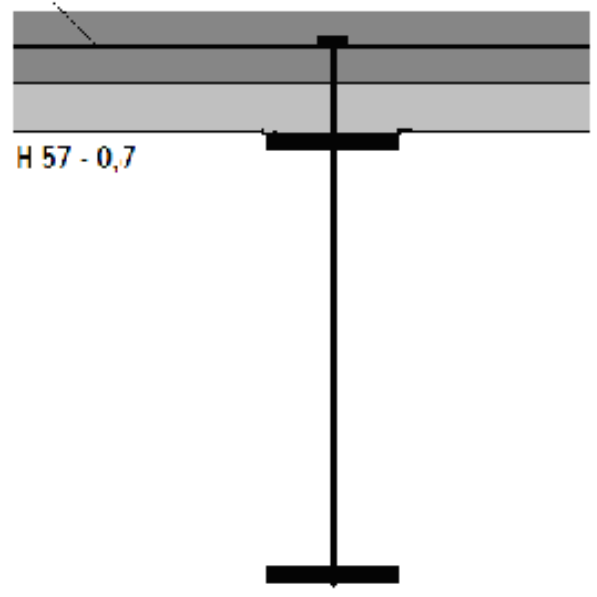

б)

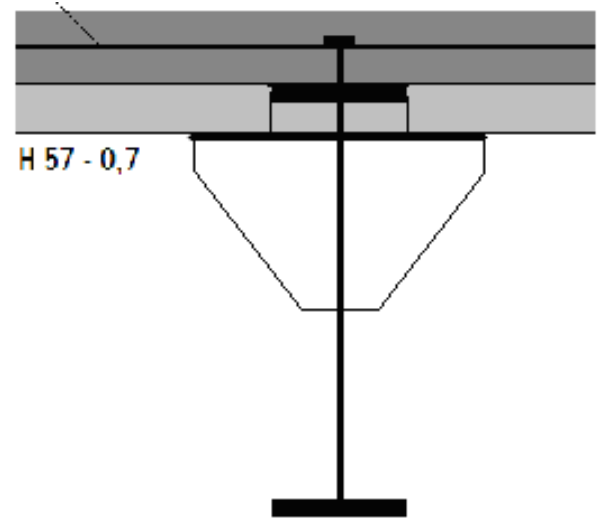

Рис. 2. Варіант монтажу другорядної балки зі зварного двотавра в одному рівні (а); 3 підвищеним розташуванням для зменшення робочої висоти перекриття (б)

Прийняті навантаження під час розрахунків заміни другорядної балки на прокатний двотавр №36 повністю відповідають державним будівельним нормам, а також національним додаткам до ДСТУ-Н Б ЕN для вказаного типу громадських будівель із урахуванням отриманих технологічних навантажень. Розрахунок балки виконаний із використанням інженерної програми RSTAB фірми DLUBAL GmbH, що базується на вимогах норм Eurocode. Обсяг розрахунків включав перевірку балки в монтажний період та в умовах проектних навантажень. Характеристики матеріалів узяті згідно 3 технічними вимогами. Проліт балки складав 8 м. Крок влаштування балок -2 м. Модель балки комбінованого перерізу та їі поперечний переріз показані на рис. 3. a)

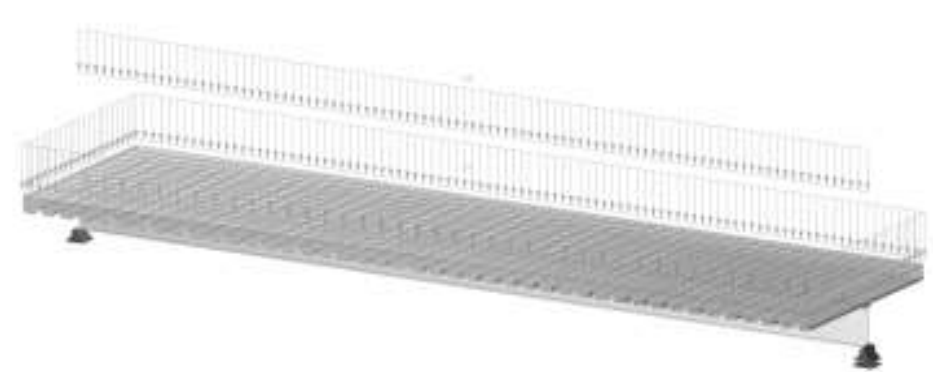

б)

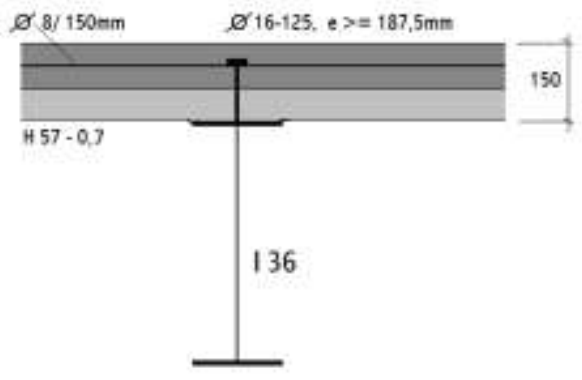

Рис. 3. Розрахункова модель (а) та поперечний переріз сталезалізобетонної балки комбінованого перерізу (б)

За результатами проведеного розрахунку підтвердилася можливість використання такого конструктивного рішення: залізобетонна плита товщиною 150 мм армована сіткою стержнів $\varnothing 8$ мм 3 кроком 150 мм та з'єднана зі сталевою балкою, виконаною 3 прокатного двотавра №36. Як з'єднувальні елементи прийняті болти фірми «Нельсон» типу КВ $16 \times 125$, які приварювалися до верхньої полички двотавра
№36 3 кроком 187 мм, кратним кроку хвилі профільованого настилу. Рекомендована схема розташування анкерів у половині прольоту (опора розташована зліва) показана на рисунку 4. Анкерні болти типу КВ 16×125 мають такі розміри: загальна висота - 125 мм; діаметр болта - 16 мм; діаметр головки болта 32 мм; висота головки болта -8 мм. 


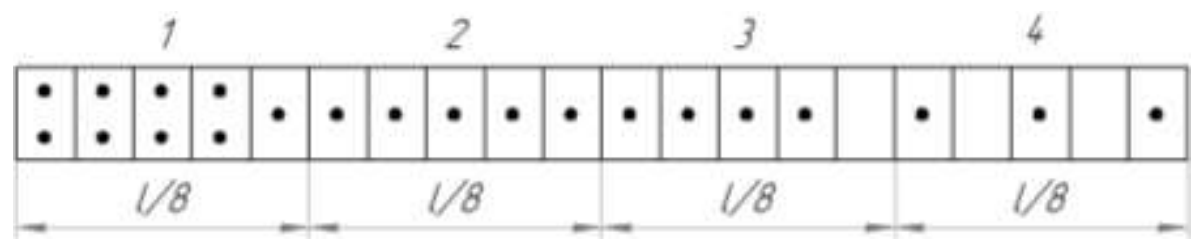

Рис. 4. Рекомендована схема розташування анкерів на половині прольоту

Результати перевірки сталезалізобетонної балки 3 різними комбінаціями навантажень підтвердили забезпечення несучої здатності за всіма показниками. Оскільки перевірка за деформаціями показала недостатню жорсткість балки, то сформульовано рекомендації, згідно 3 якими необхідно виконати будівельний підйом на стадії виготовлення $f=7$ мм. При цьому досягається максимальний експлуатаційний прогин балки $f_{\max }=31$ мм, що складає $1 / 257$ прольоту, задовольняючи при цьому вимоги норм $1 / 250$ прольоту. Власні коливання сталезалізобетонної балки запропонованого перерізу перевищують 3 Гц і складають 4,32 Гц, що задовольняє вимоги норм за хибкістю конструкцій.

Таким чином, за рахунок забезпечення сумісної роботи сталевої та залізобетонної частин сталезалізобетонної балки вдалося знизити вартість будівництва при збереженні відповідної міцності й жорсткості перекриттів будівлі, а саме:

-витрати на виготовлення конструкцій знизилися на $10 \%$;

-вага конструкції зменшилася на 13,4\%; -витрати сталі на виготовлення конструкції зменшилися на 25\%.

Єдиним недоліком

описаного конструктивного рішення $€$ необхідність виконання ще одної операції при будівництві конструкції: монолітні залізобетонні роботи (бетонування верхнього пояса, що одночасно виконує функції стиснутого пояса та плити перекриття). На рис. 5, а показані фотографії каркаса торгово-офісного комплексу 3 паркінгами у м. Київ під час монтажу.

Зниження вартості будівництва за рахунок аналогічного забезпечення сумісної роботи сталевої та залізобетонної частин сталезалізобетонної балки вдалося досягти під час будівництва перекриття в одному 3 виробничих комплексів промислового підприємства. Розроблений варіант монолітного перекриття товщиною 180 мм по сталевих балках. Спільна робота сталевої балки i монолітної плити досягалася за допомогою петльових анкерів та жорстких упорів. Балки перекриття прольотом 6 м запроектовано зі зварних двотаврів із розмірами стінки $298 \times 6$ мм і поличок $150 \times 12$ мм. Фотографія каркаса промислової будівлі під час монтажу показана на рис. 5, б.

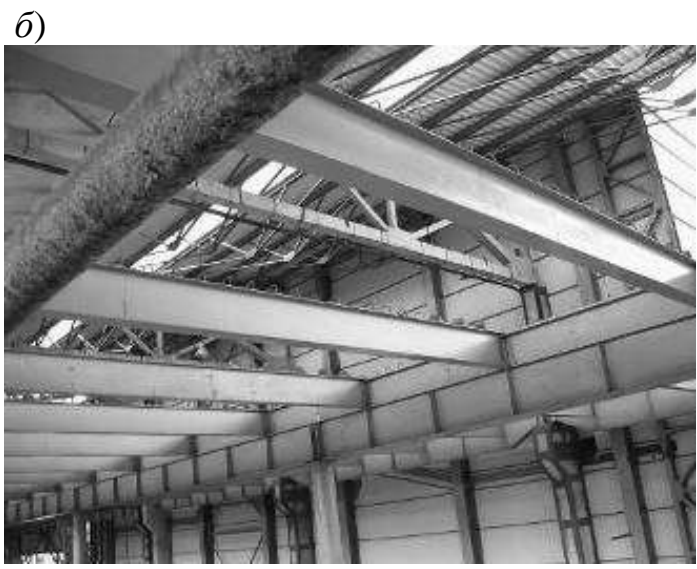

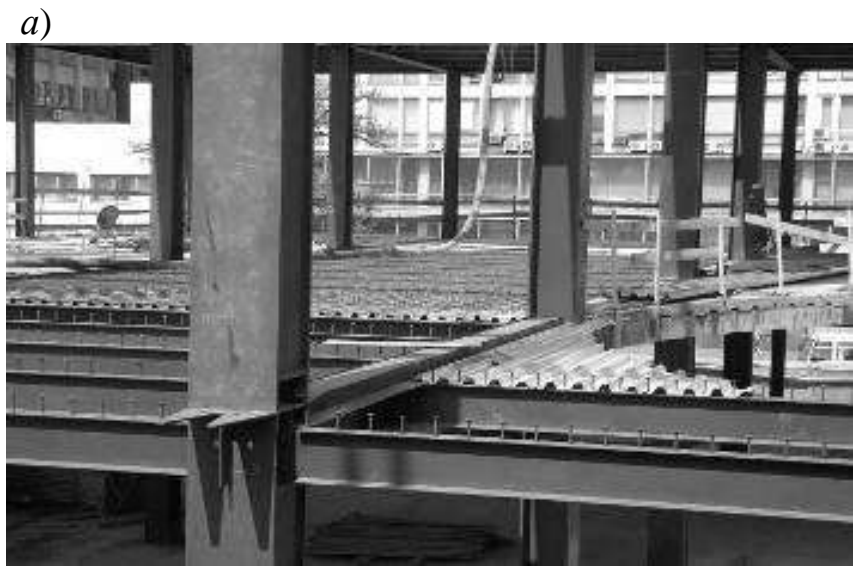

Рис. 5. Каркаси будівель під час монтажу: $a$ - торгово-офісний комплекс $з$ паркінгами у м. Київ; б - виробничий корпус промислового підприємства 
Висновки. На сьогоднішній день в Україні до кінця невирішеним питанням залишається розробка загальних правил розрахунку і проектування сталезалізобетонних конструкцій, які полягають у визначенні розмірів поперечного перерізу, кількості арматури, способів армування і забезпечення сумісної роботи. Іноземні дослідження в цьому напрямку супроводжуються ретельним експериментально-теоретичним аналізом. Тому досвід закордонного проектування сталезалізобетонних конструкцій, безсумнівно, $\epsilon$ корисним для сучасного розвитку будівництва в Україні. Технологія виготовлення засобів з'єднання «Нельсон», що розроблялася й удосконалювалася останні 30 років, дозволяє об'єднати та забезпечити спільну роботу сталевих і залізобетонних конструкцій в єдину сталезалізобетонну конструкцію і тим самим знизити витрати сталі. Анкерні засоби сприймають зсувні зусилля, які виникають між залізобетонною плитою та верхніми поясами сталевих несучих балок при розрахункових навантаженнях, i перешкоджають відриванню плити від верхніх поясів балок при прогинах конструкції перекриття.

\section{Список використаних джерел}

1. ДБН А.1.1-94:2010. Система стандартизації та нормування у будівництві. Проектування будівельних конструкцій за Єврокодами. Основні положення [Текст]: уведено вперше; чинний 3 2013-07-01. - К. : Мінрегіонбуд України, 2012. - 22 с.

2. ДБН В.2.6-160:2010. Конструкції будинків і споруд. Сталезалізобетонні конструкції. Основні положення [Текст]: уведено вперше; чинний з 2011-09-01. - К.: Мінрегіонбуд України, 2011. $-55 \mathrm{c}$.

3. Гульванесян, Х. Руководство для проектировщиков к Еврокоду 1990: Основы проектирования сооружений [Текст] / Х. Гульванесян, Ж.-А. Калгаро, М. Голицки; пер. с англ. - М.: МГСУ, 2011. $-258 \mathrm{c}$.

4. ДСТУ-Н Б ЕN 1994-1-1:2010. Сврокод 4. Проектування сталезалізобетонних конструкцій. Частина 1-1. Загальні правила і правила для споруд (EN 1994-1-1:2004, IDN) [Текст]: чинний з 201306-01. - К.: Мінрегіонбуд України, 2012. - 159 с.

5. Поєднання сталевої та бетонної частин сталезалізобетонних конструкцій за допомогою анкерів системи Nelson [Текст] / O.В. Семко, А.В. Гасенко, В.В. Дарієнко, О.І. Богуш // Комунальне господарство міст: наук.-техн. зб. Серія: Технічні науки та архітектура. - Харків: ХНАМГ, 2011. Вип. 97. - С. 77-82.

6. Семко, О.В. Визначення несучої здатності сталевих балок із урахуванням сумісної роботи зі збірними залізобетонними плитами [Текст] / О.В. Семко, С.А. Гудзь // Ресурсоекономні матеріали, конструкції, будівлі та споруди: зб. наук. праць. - Рівне, 2011. - Вип. 22. - С. 485-491.

7. Семко, О.В. Експериментально-теоретичні дослідження нерозрізних сталезалізобетонних балок $з$ гнучкими анкерами [Текст] / О.В. Семко, С.А. Гудзь, В.В. Дарієнко // Ресурсоекономні матеріали, конструкції, будівлі та споруди: зб. наук. праць. - Рівне, 2008. - Вип. 16.- С. 344-351.

8. Стороженко, Л.И. Сталежелезобетонные конструкции [Текст] / Л.И. Стороженко, А.В. Семко, В.И. Ефименко. - К.: Четверта хвиля, 1997. - 158 с.

9. Designers' Guide to Eurocode 4: Design of composite steel and concrete structures, 2th editions. Roger P. Johnson. 978-0-7277-4173-8. Published 2011.

10.EN 1994 Eurocode 4: Design of composite steel and concrete structures. EN 1994-1-1:2004 Part 11: General rules and rules for building.

11.Sykora M., Cervenka V., Holisky M. Assessment of model uncertainties in the analysis of reinforcement concrete structures // 18th International Conference «Engineering Mechanics 2012». Svratka, Czech Republic, May 14 - 17, 2012. - pp. 1263 - 1272.

Рецензент д-р техн. наук, професор С.Ф. Пічугін

Гасенко Антон Васильович, канд. техн. наук, доцент кафедри залізобетонних і кам’яних конструкцій та опору матеріалів. Полтавський національний технічний університет імені Юрія Кондратюка.

Е-пошта: Gasent@mail.ru. 
Гудзь Сергій Анатолійович, канд. техн. наук. доцент кафедри конструкцій з металу, дерева і пластмас. Полтавський національний технічний університет імені Юрія Кондратюка. Е-пошта: Haytak@meta.ua. Дарієнко Віктор Вікторович, канд. техн. наук. доцент кафедри будівельних, дорожніх машин та будівництва. Кіровоградський національний технічний університет. Е-пошта: Vdarienko@yandex.ua.

Gasenko Anton, candidate of technical sciences, associate professor of department of reinforced-concrete and stone constructions and resistance of materials of the Poltava National Technical Yuri Kondratyuk University. E-mail: Gasent@mail.ru.

Gudz Sergij, candidate of technical sciences, associate professor of department of metal, wood and plastic structures of the Poltava National Technical Yuri Kondratyuk University. E-mail: Haytak@meta.ua.

Darienko Viktor, candidate of technical sciences, associate professor of department of building, road machinery and construction of the Kirovograd National Technical University. E-mail: Vdarienko@yandex.ua. 